\title{
Serum Paraoxonase-1 (PON1) Activity and Concentration: a New Biomarker in Cirrhotic and Hepatocellular Carcinoma Egyptian Patients
}

\author{
Mofida R. Makhloof ${ }^{1}$, Dalia I, Badran², Mohamed F. Hassan ${ }^{3}$, \\ Fathalla M. Hassan ${ }^{2}$ and Mohy-Eldin A. Abdel Atty ${ }^{1}$ \\ ${ }^{I}$ Department of Chemistry, Faculty of Science, Suez Canal University, Ismailia, Egypt. \\ ${ }^{2}$ Department of Biochemistry, Faculty of Medicine, Suez Canal University, Ismailia, Egypt \\ ${ }^{3}$ Department of Endemic \& Infectious Diseases, Faculty of Medicine, Suez Canal University, \\ Ismailia, Egypt
}

Corresponding Author Mohamed Fathalla M. Hassan

Mobile:

$+201221420025$

E mail:

mfmhassan666@yaho o.com

\section{Abbreviations:}

HCC, Hepatocellular carcinoma, PON-1, paraoxnase-1, HDL, high density lipoprotein, $\quad A F P$, alpha Fetoprotein, LC, liver cirrhosis, CLD, chronic liver disease, ALT, alanine transaminase, AST, aspartate transaminase
Background and study aim: Hepatoma is the most common cancer worldwide, being regarded as the fifth of all malignancies. Mandating for a new, sensitive and specific markers for $\mathrm{HCC}$ are critically needed. Human paraoxonase-1 (PON-1), a $\mathrm{Ca}^{+2}$ dependent esterase in the liver, with antioxidant functions, and binds to the HDL particles and hence discarding carcinogenic lipid radicals as byproduct of lipid peroxidation. The aim of this study was to estimate the importance of serum PON-1 activity and concentration in HCC in Egyptian patients as a more sensitive and specific biomarker compared to an established biomarker; Alpha-fetoprotein (AFP).

Patients and Methods: This study was conducted on 88 subjects: 64 patients; 40 patients with HCC, 24 cirrhotic patients and 24 healthy subjects who admitted in Internal Medicine Department, Suez Canal University Hospital, Ismailia, Egypt.
Clinical and radiological investigations in those of the Cirrhotic, and HCC groups for viral hepatitis markers, liver function tests, serum assay of AFP and PON-1 activity and cconcentrations.

Results: The results showed that PON-1 concentration was found significantly lower in HCC patients than those of the control and Cirrhotic group $(p<0.001)$. The sensitivity and specificity of PON-1 concentration for HCC were superior to those of AFP and PON-1 activity especially in recently detected HCC. PON-1 concentration had a sensitivity of $88.3 \%$ and specificity of $90.48 \%$ at the optimal cut-off value of $70.55(\mathrm{ng} / \mathrm{ml})$. AFP gives a sensitivity of $82.50 \%$ and specificity of 73.08 at a cutoff $20.44 \mathrm{ng} / \mathrm{ml}$.

Conclusion: This study demonstrates that PON1 concentration and activity were superior to AFP in the recently detected HCC.

\section{INTRODUCTION}

Hepatoma is the commonest primary liver cancer. Major etiologic factors for HCC are longstanding infections with hepatotropic viruses; hepatitis B virus (HBV), hepatitis $\mathrm{C}$ virus (HCV), the exposure to aflatoxin- $b$ and excessive alcohol consumption [1].

Poor life expectancy in HCC patients with a less than 5\% 5-year survival rate. Screening strategies every 6 month in Cirrhotic patients including AFP and ultrasound[3]. However, Diagnostic AFP is a marker with poor sensitivity and specificity [2] and the ultrasound is dependent on the experience of the operator [3].

Makhloof et al., Afro-Egypt J Infect Endem Dis 2019; 9(2): 185-192

https://aeji.journals.ekb.eg/

http://mis.zu.edu.eg/ajied/home.aspx
Human serum paraoxonase-1 (PON1) that has lipophilic antioxidant characteristics. Participating in the removal and clearing of organophosphorus compounds. Also, by removal of carcinogenic lipid soluble radicals as byproduct of lipid peroxidation. PON-1 is one of the endogenous free-radical scavenging systems in the human body $[4,5]$. PON-1 is manifactured in the liver and secreted into the blood, bound to less than $10 \%$ of the total high-density lipoprotein (HDL) particles [5,9]. Reduced PON-1 activity, with increased oxidative stress in diabetes mellitus, hypercholesterolemia, and cardiovascular disease $[\mathbf{6 , 2 0 , 2 8}]$. 
Hence, serum PON1 activity reflecting an index of liver function status $[\mathbf{9 , 1 0 ]}$. Preliminary studies demonstrated decreased serum arylesterase activity significantly in Cirrhotic patients [7,8]. Previous investigators have measured PON1 activity were decreased significantly in serum of chronic liver disease patients such as; alcoholic liver disease, chronic hepatitis, and cirrhosis [9-13]. Kilic et al. have demonstrated that decreased serum arylesterase activity significantly in patients with chronic hepatitis [13]. Additionally, Xu et al. have shown that successful liver transplantation increased PON1 activity which was previously decreased PON1 activity in chronic liver diseases [14]. PON1 has been shown to protect liver damage by eliminating oxidative stress by $\mathrm{CCl}_{4}$ [15]. Furthermore, Marsillach et al. have reported that PON1 protects hepatocytes against inflammation, fibrosis and thus liver diseases [16]. Kedage et al., demonstrated that liver disorders showing decreased Serum Paraoxonase 1 Activity Status [17].

The present work aimed to investigate the usefulness of biomarkers as serum PON1 activity and concentration in cirrhotic and HCC patients as a sensitive and specific test by comparing it with an already established biomarker as AFP.

\section{SUBJECTS AND METHODS}

\section{Subjects}

This cohort prospective descriptive study was carried out in the Internal Medicine, Biochemistry Departments, Suez Canal University Hospital and Chemistry department of Faculty of Science, Suez Canal University, Ismailia, Egypt, during the Period from 19 March 2017 to 31 September 2017.

Eighty-eight subjects; 64 patients and 24 healthy controls were conducted in this study and classified into three groups:

Group 1. HCC group included 40 patients with HCC (26 males and 14 females, their mean age are $56 \pm 9.5$ years old). Those were diagnosed according to clinical examination, laboratory and radiological investigations including abdominal Ultrasonography and Triphasic abdominal C.T. Scan. HCC patients clinical data were collected to determine tumor characteristics as tumor number, size, and micro/macrovascular involvement.

Group 2. Liver Cirrhotic (LC) group, including 24 patients $(17$ males and 7 females, their mean age is $56.3 \pm 10.3$ years old). The diagnosis of cirrhosis was based on clinical, biochemical, and ultrasonography.

Group 3. Control group, including 24 apparently healthy volunteers (18 males and 6 females, their mean age are $52.83 \pm 7.47$ years old). The control group had no evidence of liver disease by clinical or biochemical or imaging paramaters or known current medical illness at recruitment. All controls were not diabetics, negative viral serological markers. All patients and controls gave their informed consent which was ethically conducted in accordance with the Helsinki Declaration.

\section{Blood sampling:}

Six milliliters of venous blood samples were taken, from each participant and divided into, $2 \mathrm{ml}$ in tube containing sodium citrate for prothrombin time and the rest of blood was left to clot, then the serum was separated by 10 minutes centrifugation at $2300 \mathrm{~g}$ and the serum samples then collected, divided into aliquots and stored at $-20 \mathrm{oC}$ for further analysis.

\section{Laboratory investigations:}

Liver function tests in the form of serum alanine aminotransferase (ALT), aspartate aminotransferase (AST), alkaline phosphatase (ALP), direct bilirubin and total bilirubin, total Protein, Albumin, prothrombin time (PT), and hepatitis viral markers including $\mathrm{HCV}$ antibody and HBsAg.

\section{Tumor markers:}

The serum concentration of AFP was determined by enzyme-linked immunosorbent assay (ELISA)AFP Kit (Genway Company, USA) according to the method described in [18]. PON1 activity was measured using commercially available kits (Relassay®; Turkey) [19]. Enzyme-linked immunosorbent assay (ELISA) is used to determine PON1 concentration and activity [20].

\section{RESULTS}

The Demographic data of the studied groups: according to the severity of liver disease using Child Classification in the Cirrhotic (LC) and HCC groups, classified as $17.5 \%$ of HCC group were child A, $35 \%$ were child B and $47.5 \%$ were child C compared to $33.3 \%, 54.2 \%$ and $12.5 \%$ in the LC group respectively. 
Table (1): Liver Function Tests of the study groups

\begin{tabular}{|c|c|c|c|c|c|c|c|}
\hline Parameter & Group & $\mathbf{N}$ & Mean \pm SD & Test-value & $\begin{array}{c}\text { P } \\
\text { For all } \\
\text { groups }\end{array}$ & $\begin{array}{r}\text { Bet } \\
\text { c }\end{array}$ & $\begin{array}{l}\text { groups } \\
\text { cison }\end{array}$ \\
\hline \multirow{3}{*}{$\begin{array}{c}\text { AST } \\
(\mathbf{U} / \mathbf{L})\end{array}$} & control & 24 & $26 \pm 8.9$ & \multirow{3}{*}{24.664} & \multirow{3}{*}{$<0.001$} & $\overline{\mathrm{P}_{1}}$ & $<0.01$ \\
\hline & $\mathrm{LC}$ & 24 & $49.5 \pm 25.1$ & & & $\overline{\mathrm{P}_{2}}$ & $<0.01$ \\
\hline & $\mathrm{HCC}$ & 40 & $63.6 \pm 43.8$ & & & $\mathrm{P}_{3}$ & $<0.05$ \\
\hline \multirow{3}{*}{$\underset{(\mathbf{U} / \mathbf{L})}{\mathbf{A L T}}$} & control & 24 & $18.8 \pm 8.6$ & \multirow{3}{*}{30.757} & \multirow{3}{*}{$<0.001$} & $\overline{P_{1}}$ & $<0.01$ \\
\hline & $\mathrm{LC}$ & 24 & $33.5 \pm 15.8$ & & & $\overline{\mathrm{P}_{2}}$ & $<0.01$ \\
\hline & $\mathrm{HCC}$ & 40 & $50.5 \pm 40.0$ & & & $\overline{\mathrm{P}_{3}}$ & $>0.05$ \\
\hline \multirow{3}{*}{$\begin{array}{l}\mathbf{A L P} \\
(\mathbf{U} / \mathbf{L})\end{array}$} & control & 24 & $64.33 \pm 17.3$ & \multirow{3}{*}{23.68} & \multirow{3}{*}{$<0.001$} & $\overline{\mathrm{P}_{1}}$ & $<0.01$ \\
\hline & $\mathrm{LC}$ & 24 & $89.83 \pm 56.84$ & & & $\overline{\mathrm{P}_{2}}$ & $<0.01$ \\
\hline & $\mathrm{HCC}$ & 40 & $167.68 \pm 80.7$ & & & $\overline{\mathrm{P}_{3}}$ & $<0.01$ \\
\hline \multirow{3}{*}{$\begin{array}{l}\text { Total bilirubin } \\
\qquad(\mathrm{mg} / \mathrm{dl})\end{array}$} & control & 24 & $0.86 \pm 0.23$ & \multirow{3}{*}{47.357} & \multirow{3}{*}{$<0.001$} & $\overline{\mathrm{P} 1}$ & $<0.01$ \\
\hline & $\mathrm{LC}$ & 24 & $4.3 \pm 4.7$ & & & $\overline{\mathrm{P}_{2}}$ & $<0.01$ \\
\hline & $\mathrm{HCC}$ & 40 & $6.1 \pm 4.9$ & & & $\overline{\mathrm{P}_{3}}$ & $>0.05$ \\
\hline \multirow{3}{*}{$\begin{array}{c}\text { Direct } \\
\text { bilirubin } \\
\text { (mg/dl) }\end{array}$} & control & 24 & $0.13 \pm 0.04$ & \multirow[t]{3}{*}{52.007} & \multirow{3}{*}{$<0.001$} & $\overline{\mathrm{P}_{1}}$ & $<0.01$ \\
\hline & $\mathrm{LC}$ & 24 & $2.03 \pm 2.33$ & & & $\overline{\mathrm{P}_{2}}$ & $<0.01$ \\
\hline & $\mathrm{HCC}$ & 40 & $2.3 \pm 1.87$ & & & $\mathrm{P}_{3}$ & $>0.05$ \\
\hline \multirow{3}{*}{$\begin{array}{c}\text { Total } \\
\text { protein } \\
(\mathrm{g} / \mathrm{L})\end{array}$} & control & 24 & $7.93 \pm 0.55$ & \multirow[t]{3}{*}{55.138} & \multirow{3}{*}{$<0.001$} & $\overline{\mathrm{P}_{1}}$ & $<0.01$ \\
\hline & $\mathrm{LC}$ & 24 & $5.61 \pm 1.10$ & & & $\overline{\mathrm{P}_{2}}$ & $<0.01$ \\
\hline & $\mathrm{HCC}$ & 40 & $5.74 \pm 0.92$ & & & $\overline{\mathrm{P}_{3}}$ & $<0.01$ \\
\hline \multirow{3}{*}{$\begin{array}{c}\text { Albumin } \\
(\mathrm{g} / \mathrm{L})\end{array}$} & control & 24 & $4.6 \pm 0.67$ & \multirow[t]{3}{*}{112.631} & \multirow{3}{*}{$<0.001$} & $\overline{\mathrm{P}_{1}}$ & $<0.01$ \\
\hline & $\mathrm{LC}$ & 24 & $2.9 \pm 0.96$ & & & $\mathrm{P}_{2}$ & $<0.01$ \\
\hline & $\mathrm{HCC}$ & 40 & $2.1 \pm 0.34$ & & & $\mathrm{P}_{3}$ & $<0.01$ \\
\hline
\end{tabular}

$\mathrm{t}_{1} \& \mathrm{p}_{1}$ difference between LC group and the control group, $\mathrm{t}_{2} \& \mathrm{p}_{2}$ difference between HCC group and the control group and $\mathrm{t} 3 \& \mathrm{p} 3$ difference between $\mathrm{HCC}$ group and the LC group, $\mathrm{P}<0.05$ (significant), $\mathrm{P}>0.05$ (insignificant)

Laboratory tests for liver function identified in Table 1. There was a significant increase in the mean level of serum AST, ALT, ALP and increase in serum total bilirubin and a significant decline in the mean level of serum albumin, total protein in both LC and HCC groups compared to the control group $\mathrm{p}=0.001$. Although, total serum bilirubin, ALT and serum albumin showed no statistically significant difference was observed between cirrhotic and HCC. The mean level of AST and Alkaline phosphatase was decreased in the cirrhotic group than the HCC group $(\mathrm{P}<0.01)$.

Table (2): Comparison between the studied groups according to serum levels of AFP, PON1 concentration and activity.

\begin{tabular}{|c|c|c|c|c|c|c|c|c|c|}
\hline Parameter & Group & $\mathbf{N}$ & Range & Mean \pm SD & \multicolumn{2}{|c|}{ Median } & \multicolumn{2}{|c|}{ t-value } & \multicolumn{2}{|c|}{ p-value } \\
\hline \multirow{4}{*}{$\begin{array}{c}\text { AFP } \\
(\mathrm{ng} / \mathrm{ml})\end{array}$} & control & 24 & $0.86-7.24$ & $3.0 \pm 1.6$ & 3.06 & $\mathrm{t}_{1}$ & 2.11 & $\mathrm{p}_{1}$ & $<0.001$ \\
\cline { 2 - 10 } & $\mathrm{LC}$ & 24 & $0.61-31.00$ & $6.38 \pm 7.66$ & 2.7450 & $\mathrm{t}_{2}$ & 5.05 & $\mathrm{p}_{2}$ & $<0.001$ \\
\cline { 2 - 10 } & $\mathrm{HCC}$ & 40 & $4.40-1337.00$ & $323.30 \pm 401.03$ & 130.95 & $\mathrm{t}_{3}$ & 4.99 & $\mathrm{p}_{3}$ & $<0.001$ \\
\hline $\begin{array}{c}\text { PON1 } \\
\text { concentration } \\
(\mathrm{g} / \mathrm{ml})\end{array}$ & control & 24 & $55.00-89$ & $74.6 \pm 8.7$ & 76.00 & $\mathrm{t}_{1}$ & -8.04 & $\mathrm{p}_{1}$ & $<0.001$ \\
\cline { 2 - 10 } & $\mathrm{LC}$ & 24 & $55.00-151.00$ & $108.3 \pm 28.1$ & 110.50 & $\mathrm{t}_{2}$ & -14.03 & $\mathrm{p}_{2}$ & $<0.001$ \\
\cline { 2 - 10 } & $\mathrm{HCC}$ & 40 & $19.00-88.00$ & $47.9 \pm 15.3$ & 46.50 & $\mathrm{t}_{3}$ & -9.70 & $\mathrm{p}_{3}$ & $<0.001$ \\
\hline \multirow{3}{*}{$\begin{array}{c}\text { PON1 activity } \\
(\mathrm{U} / \mathrm{L})\end{array}$} & control & 24 & $111.00-316.00$ & $210.5 \pm 55.5$ & 201.5000 & $\mathrm{t}_{1}$ & 14.39 & $\mathrm{p}_{1}$ & $<0.001$ \\
\cline { 2 - 10 } & $\mathrm{LC}$ & 24 & $113.00-211.00$ & $149.3 \pm 23.9$ & 110.50 & $\mathrm{t}_{2}$ & 5.90 & $\mathrm{p}_{2}$ & $<0.001$ \\
\cline { 2 - 10 } & $\mathrm{HCC}$ & 40 & $49.00-152.00$ & $104.9 \pm 30.4$ & 106.00 & $\mathrm{t}_{3}$ & -6.48 & $\mathrm{p}_{3}$ & $<0.001$ \\
\hline
\end{tabular}

$\mathrm{t}_{1} \& \mathrm{p}_{1}$ difference between LC group and the control group, $\mathrm{t}_{2} \& \mathrm{p}_{2}$ difference between HCC group and the control group and $\mathrm{t} 3 \& \mathrm{p} 3$ difference between HCC group and the LC group, $\mathrm{P}<0.05$ (significant), $\mathrm{P}>0.05$ (insignificant) 
As illustrated in the table 2 and Figure 5, HCC patients had significantly higher serum AFP (ng/ml) compared to both the control group (323.30 \pm 401.03 vs. $3.0 \pm 1.6)(\mathrm{p}<0.001)$ and to LC patients $(323.30 \pm 401.03$ vs $6.38 \pm 7.66)(\mathrm{p}<0.001)$, and still significantly higher in the LC patients compared to the control group $(6.38 \pm 7.66$ vs. $2.79 \pm 1.26)$ $(\mathrm{P}<0.001)$.

Regarding to the results of mean serum levels of PON1 concentration level (ng/ml), table 2, Figure 1 showed a significant reduced levels in the HCC group compared to the controls $(47.9 \pm 15$ vs 74.6 $\pm 8.7)(\mathrm{P}<0.001)$ and to the LC group $(47.9 \pm 15$ vs $108.3 \pm 28.1)(\mathrm{P}<0.001)$. Furthermore, an increase in serum PON1 concentration significantly was found in the LC group compared to the control group (108.3 28.1 vs 74.6 $\pm 8.7 \quad(\mathrm{P}<0.001)$. Regarding the PON1 activity, table 2 shows also a significant reduced serum PON1 activity (U/L) level in the HCC patients compared to the controls $(104.9 \pm 30.4$ vs $210.5 \pm 55.5)(\mathrm{P}<0.001)$ and to the LC patients (104.9 $\pm 30.4 v s .149 .3 \pm 23.9)$ $(\mathrm{P}<0.001)$. While in the LC group, a significant decrease in serum PON1 activity level was found in the LC group compared to the control group $(149.3 \pm 23.9$ vs $210.5 \pm 55.5)(\mathrm{P}<0.001)$.

Serum PON1 concentration shows a significant difference in results among the different Child-

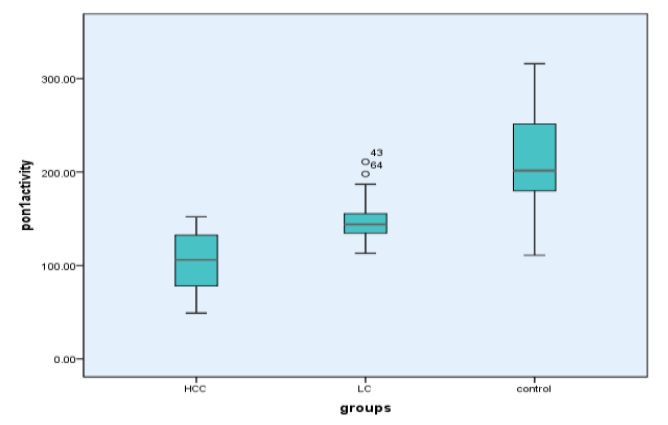

A: Comparison between PON1 activity levels in Patients with HCC, LC and control subjects
Pugh classes $\quad\left(\mathrm{p}_{1}<0.05 . \quad \mathrm{p}_{2}<0.001, \quad \mathrm{p}_{3}<0.05\right)$ respectively. Serum PON1 activity is significantly higher in Child A than child $\mathrm{C}$ ( $\mathrm{p} 2<0.05)$, but there is no significant difference between the other groups: child $\mathrm{B}$ and child $\mathrm{C}$, and Child A and child B $\left(\mathrm{p}_{1}>0.05\right),\left(\mathrm{p}_{3}>0.05\right)$. Serum AFP concentration is significantly higher in Child A than Child C $\left(\mathrm{p}_{2}<0.05\right)$ and Child B than Child C $\left(\mathrm{p}_{3}<0.05\right)$, but there is no significant difference between Child A and Child B (Table 4).

\section{Diagnostic Performance of studied markers}

Analysis of the data in the ROC curve as in (Table 4, Figure 2), it showed the cut-off value (which had the highest Youden's index) for AFP to differentiate HCC from LC patients of 20.44 $\mathrm{ng} / \mathrm{ml}$. This gave $82.50 \%$ in sensitivity, $73.08 \%$ in specificity, $82.50 \%$ in PPV, $79.17 \%$ in NPV. The area under the ROC curve (AUROC) was 0.92 .

On the other hand, the cutoff is at a value 121.58 (U/L), serum PON1 activity had a sensitivity of $82.50 \%$, a specificity of $70.83 \%$. The PPV was $82.50 \%$ and the NPV was $70.83 \%$. The AUROC was 0.86 .

Furthermore, at 70.55 (U/L) optimal cut-off serum PON1 concentration had $88.37 \%$ sensitivity and 90.48\% specificity. Positive Predictive Value PPV 95.00\%, NPV 79.17\% and AUROC was 0.96.



B: Comparison between PON1 concentration levels in Patients with HCC, LC and control subjects

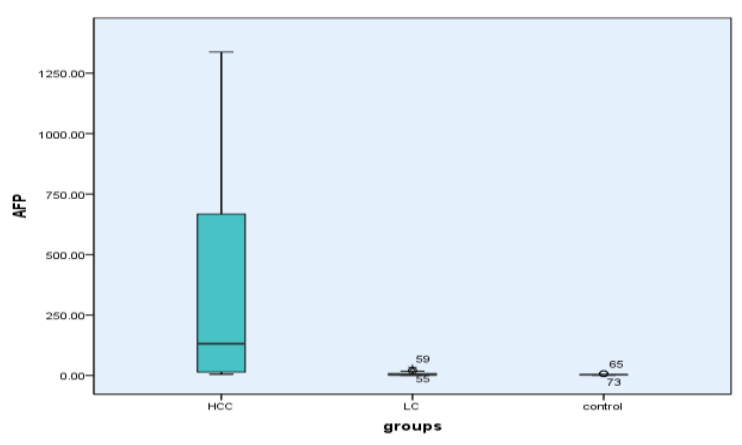

C: Comparison between AFP levels in patients with HCC, LC and control subjects.

Figure 1: Box plots showing the level of studied markers in the HCC, LC and control groups

Makhloof et al., Afro-Egypt J Infect Endem Dis 2019; 9(2): 185-192

https://aeji.journals.ekb.eg/

http://mis.zu.edu.eg/ajied/home.aspx 
Table (3): Comparison of serum AFP, PON1 concentration and PON1 activity in HCC group according to Child-Pugh class

\begin{tabular}{|c|c|c|c|c|c|c|c|c|c|}
\hline Parameter & $\begin{array}{l}\text { Child- } \\
\text { Pugh }\end{array}$ & NO. \% & Range & Mean \pm SD & Median & \multicolumn{2}{|c|}{ t-value } & \multicolumn{2}{|c|}{ P-value } \\
\hline \multirow{3}{*}{$\begin{array}{l}\text { AFP } \\
(\mathrm{ng} / \mathrm{ml})\end{array}$} & Class A & $7(17.5)$ & $6-131.9$ & $29.29 \pm 45.46$ & 14.61 & $\mathrm{t}_{1}$ & -0.79 & $p_{1}$ & $>0.05$ \\
\hline & Class B & $14(35)$ & $4.4-602$ & $78.48 \pm 160.55$ & 303.5 & $t_{2}$ & -3.78 & $\mathrm{p}_{2}$ & $<0.05$ \\
\hline & Class C & $19(47)$ & $128.18-1337$ & $612.02 \pm 401.16$ & 731.30 & $t_{3}$ & -5.23 & $\mathrm{p}_{3}$ & $<0.001$ \\
\hline \multirow{3}{*}{$\begin{array}{c}\text { PON1 } \\
\text { concentration } \\
(\mathrm{ng} / \mathrm{ml})\end{array}$} & Class A & $7(17.5)$ & ग1-80 & 66.4 & 66.0 & $\mathrm{t}_{1}$ & 2.84 & $\mathrm{p}_{1}$ & $<0.05$ \\
\hline & Class B & $14(35)$ & $32-69$ & $50.0 \pm 12.42$ & 46.5 & $\mathrm{t}_{2}$ & 5.18 & $\mathrm{p}_{2}$ & $<0.001$ \\
\hline & Class C & $19(47)$ & $19-58$ & $39.578 \pm 12.42$ & 43.00 & $\mathrm{t}_{3}$ & 2.50 & $p_{3}$ & $<0.05$ \\
\hline \multirow{3}{*}{$\begin{array}{l}\text { PON1 activity } \\
\text { (U/L) }\end{array}$} & Class A & $7(17.5)$ & $111-145$ & $125.86 \pm 13.16$ & 123.00 & $\overline{t_{1}}$ & 1.64 & $p_{1}$ & $>0.05$ \\
\hline & Class B & $14(35)$ & $59-150$ & $106.93 \pm 28.87$ & 99.00 & $t_{2}$ & 3.33 & $\mathrm{p}_{2}$ & $<0.05$ \\
\hline & Class C & $19(47)$ & $49-152$ & $95.74 \pm 32.94$ & 86.00 & $t_{3}$ & 1.04 & $\mathrm{p}_{3}$ & $>0.05$ \\
\hline
\end{tabular}

$\mathrm{t}_{1} \& \mathrm{p}_{1}$ difference between the A class and the B class , $\mathrm{t}_{2} \& \mathrm{p}_{2}$ difference between A class and the C class and $\mathrm{t}_{3}$ $\& \mathrm{p}_{3}$ difference between $\mathrm{B}$ class and $\mathrm{C}$ class, $\mathrm{P}<0.05$ (significant), $\mathrm{P}>0.05$ (insignificant).

Serum PON1 concentration shows a significant difference in results among the different ChildPugh classes $\quad\left(\mathrm{p}_{1}<0.05 . \quad \mathrm{p}_{2}<0.001, \mathrm{p}_{3}<0.05\right)$ respectively. Child A had significantly higher Serum PON1 activity than Child C (p2<0.05), but there is no significant difference between
Child B and Child C, and Child A and Child B $\left(\mathrm{p}_{1}>0.05\right),\left(\mathrm{p}_{3}>0.05\right)$. Serum AFP concentration is significantly higher in Child $\mathrm{C}$ than Child A $\left(\mathrm{p}_{2}<0.05\right)$ and Child $\mathrm{B}\left(\mathrm{p}_{3}<0.05\right)$, but there is no significant difference between Child A and child B (Table 4).

Table (4): Analysis showing Cut-off, Sensitivity, Specificity, AUC, PPV and NPV of the Studied Markers

\begin{tabular}{|l|c|c|c|}
\hline \multicolumn{1}{|c|}{ Parameter } & $\begin{array}{c}\text { AFP } \\
(\mathbf{n g} / \mathbf{m l})\end{array}$ & $\begin{array}{c}\text { PON1 activity } \\
(\mathbf{U} / \mathbf{L})\end{array}$ & $\begin{array}{c}\text { PON1 concentration } \\
(\mathbf{n g} / \mathbf{m l})\end{array}$ \\
\hline Cut off value & 20.44 & 121.58 & 70.55 \\
\hline Sensitivity (\%) & 86.84 & 82.50 & 88.37 \\
\hline Specificity (\%) & 73.08 & 70.83 & 90.48 \\
\hline Positive predictive value (\%) & 82.50 & 82.50 & 95.00 \\
\hline Negative predictive value (\%) & 79.17 & 70.83 & 79.17 \\
\hline Youden's index & 0.60 & 0.53 & 0.79 \\
\hline Area Under the ROC & 0.92 & 0.86 & 0.96 \\
\hline P- value & $<0.001$ & $<0.001$ & $<0.001$ \\
\hline
\end{tabular}

$\mathrm{PPV}=$ Positive predictive value.

$\mathrm{NPV}=$ Negative predictive value

\section{Diagnostic Performance of studied markers}

Analysis of the data in the ROC curve as in (Table 4, Figure 2), it showed the cut-off value (which had the highest Youden's index) for AFP to differentiate HCC from LC patients of $20.44 \mathrm{ng} / \mathrm{ml}$. This gave $82.50 \%$ in sensitivity, $73.08 \%$ in specificity, $82.50 \%$ in PPV, $79.17 \%$ in NPV. The area under the ROC curve (AUROC) was 0.92 .
On the other hand, the cutoff is at a value 121.58 (U/L), serum PON1 activity had a sensitivity of $82.50 \%$, a specificity of $70.83 \%$. The PPV was $82.50 \%$ and the NPV was $70.83 \%$. The AUROC was 0.86 . Furthermore, at 70.55 (U/L) optimal cut-off serum PON1 concentration had $88.37 \%$ sensitivity and $90.48 \%$ specificity. Positive Predictive Value PPV 95.00\%, NPV 79.17\% and AUROC was 0.

Makhloof et al., Afro-Egypt J Infect Endem Dis 2019; 9(2): 185-192 


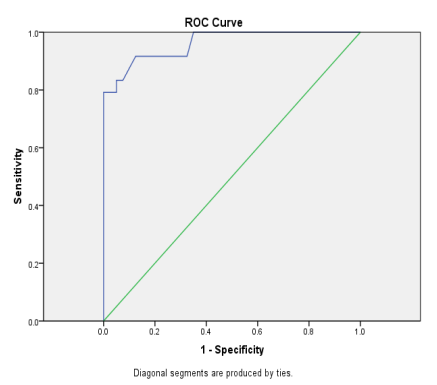

A: PON1 concentrations: ROC curve

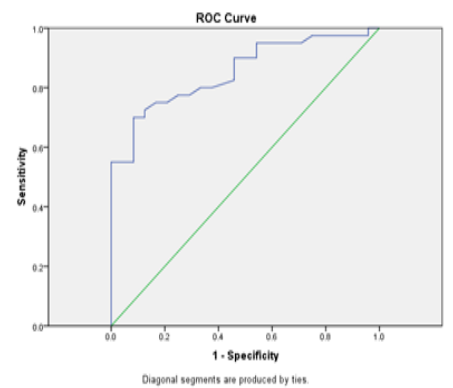

B: PON1 activity: ROC curve

Figure 2: The diagnostic performance of the studied markers in HCC patients vs. LC patients

\section{DISCUSSION}

The malignant transformation from Liver Cirrhosis to HCC is usually asymptomatic, being diagnosis late and thus increased mortality rate. The diagnosis of HCC in cirrhotic patients is often based on surveillance strategies every 6 months whose mainstay is the measurement of the levels of AFP [21] and ultrasound [3,21]. The performance characteristics of AFP as a screening diagnostic test apparently to be less satisfactory than its use as a prognostic test. Thus, there is a great need to establish another method for screening and diagnosis as early as possible for HCC [21]. PON 1 enzyme is a calcium-dependent glycoprotein produced in the liver and associated HDL4 $[4,27,28]$. PON1 prevents oxidative modification of low-density lipoprotein (LDL) particles and eliminating carcinogenic lipid-soluble radicals [4].

In this study, HCC patients showed significantly reduced serum PON1 concentration compared with LC and healthy controls $(\mathrm{P}<0.001)$, with optimal cutoff 70.55 showed a higher performance than serum AFP with optimal cutoff $20.44 \mathrm{ng} / \mathrm{ml}$ in diagnostic sensitivity ( $88.37 \%$ vs. $82.50 \%)$, specificity (90.48\% vs. $73.08 \%)$, PPV (95.0\% vs. 82.50), NPV (79.17\% vs. 79.17) and AUROC was (0.96 vs. 0.92). Abdel Wahab et al. [22], studied the combination of potential circulating proteins in serum that are differentially expressed in HCC patients associated with $\mathrm{HCV}$ infection, in order to be used as a surrogate marker in early detection of HCC. They demonstrated that identified proteins including PON1 are linked to complement activation, coagulation cascades and lipids metabolism in HCV-related HCC patients.

In another study [23], PON1 concentration was first reported as being a novel biomarker in HCC microvascular invasion (MVI). Furthermore, a study by Zhang et al. [24] reported the potential value of this elevated levels of PON1 protein for early detection of HCC. Additionally,the fucosylated PON1 may serve as a glycan biomarker for distinguishing early $\mathrm{HCC}$ from LC patients even with low AFP levels [24].

Additionally, we found that serum PON1 activity cutoff is at a value $121.58(\mathrm{U} / \mathrm{L})$, showed lower performance than serum AFP with optimal cutoff 20.44 sensitivity of $(82.50 \%$ vs $86.0 \%)$, a specificity of (70.83\% vs $73.08 \%)$. The PPV was $(82.50 \%$ vs. $80.15 \%)$ and the NPV was $(70.83 \%$ vs. $79.17 \%$ ) and AUROC was (0.86 vs. 0.92). A probable explanation of the decrease in serum PON1 may result from the suppression of PON1 attributed to the increased generation of reactive oxygen species in LC and HCC.

In the current study, we found an increased serum PON1 concentration despite decreased PON1 activity associated with the LC patients. This finding may initially appear contradictory, but it agrees with the previous observation of reduced PON1 activity and increased concentration in chronic liver patients $[\mathbf{2 5 , 2 6 ]}$. The explanation of the increase was related to an inhibition of apoptosis in liver parenchymal cells [27]. Another evidence indicates that HDL inhibits cell apoptosis and that oxidized HDL loses this capability [27]. Also, the possibility for PON1, which is known to protect HDL from oxidation, would encourage the anti-apoptotic potential of HDL [27]. Serum PON-1 concentration was proved to be superior to Alpha-fetoprotein and PON-1 activity for early detection of HCC patients being highly sensitive and specific. 
The results of this study suggest that serum enzyme concentration PON1 may be regarded as reliable biomarkers of the degree of hepatocellular damage and hepatocellular carcinoma in all studied patients groups, as it highly increased in the LC group while decreased in $\mathrm{HCC}$ group $(\mathrm{P}<0.001)$.

\section{CONCLUSION}

Hepatoma is the commonest primary liver cancer. Screening strategies every 6 months including AFP and ultrasound in cirrhotic patients. AFP, however, is a screening diagnostic marker with poor sensitivity and specificity and the ultrasound is highly dependent on the operator's experience.

The present work demonstrates the usefulness of biomarkers as serum PON1 activity and concentration in cirrhotics and HCC patients as a more sensitive and specific biomarker by comparing it with an established biomarker as AFP.

\section{Ethical approval:}

Consent for an interview was taken from each participant, who was assured about the confidentiality of his information. The faculty of medicine Suez Canal University research ethics committee approved the study

Funding: None

Conflicts of interest: There are no conflicts of interest

\section{REFERENCES}

1- Farazi P.A. and DePinho R.A. The genetic and environmental basis of hepatocellular carcinoma. Discov. Med., 2006, 6: 182-186.

2- Bertino G, Ardiri A, Malaguarnera M, Malaguarnera G, Bertino NC, and Calvagnoa S. Hepatocellular Carcinoma Serum Markers, Seminars in Oncology, Volume 39, Issue 4, August 2012, page 410-433

3- Trinchet JC, Chaffaut C, Bourcier V, Degos F, Henrion J, Fontaine $\mathrm{H}$, et al. Ultrasonographic surveillance of hepatocellular carcinoma in cirrhosis: a randomized trial comparing 3- and 6month periodicities. Hepatology Dec; 2011, 54(6): 1987-1997

4- Aviram M, Rosenblat M, Bisgaier CL, Newton RS, Primo-Parmo SL, La Du BN. Paraoxonase inhibits high-density lipoprotein oxidation and preserves its functions. A possible peroxidative role for paraoxonase. J Clin Invest.; 1998, 101:1581-1590
5- Li HL, Liu DP, Liang CC. Paraoxonase gene polymorphisms, oxidative stress, and diseases. $J$ Mol Med.; 2003, 81:766-779.

6 Ayub A, Mackness MI, Arrol S, Mackness B, Patel J, Durrington PN. Serum paraoxonase after myocardial infarction. Arterioscler Thromb Vasc Biol.; 1999, 19:330-5.

7- Burlina A, Galzigna L. Serum arylesterase isoenzymes in chronic hepatitis. Clin Biochem. 1974; 17:202-5. [PubMed]

8. Burlina A, Michielin E, Galzigna L. Characteristics and behavior of arylesterase in human serum and liver. Eur J Clin Invest. 1977;7:17-20. [PubMed]

9- Ferré N, Camps J, Prats E, Vilella E, Paul A, Figuera L, et al. Serum paraoxonase activity: A new additional test for the improved evaluation of chronic liver damage. Clin Chem. 2002; 48:2618. [PubMed]

10- Ferré N, Marsillach J, Camps J, Mackness B, Mackness M, Riu F, et al. Paraoxonase-1 is associated with oxidative stress, fibrosis and FAS expression in chronic liver diseases. $J$ Hepatol. 2006; 45:51-9. [PubMed]

11. Marsillach J, Ferré N, Vila MC, Lligoña A, Mackness $\mathrm{B}$, Mackness M, et al. Serum paraoxonase-1 in chronic alcoholics: Relationship with liver disease. Clin Biochem. 2007; 40:645-50. [PubMed]

12. Prakash M, Shetty JK, Tripathy S, Verma M, Vasudeva S, Bhandary VB. Serum paraoxonase in alcohol abusers associated with alcoholic liver disease. Clin Chim Acta. 2007;378:232-4. [PubMed]

13. Kilic SS, Aydin S, Kilic N, Erman F, Aydin S, Celik I. Serum arylesterase and paraoxonase activity in patients with chronic hepatitis. World $J$ Gastroenterol. 2005; 11:7351-4. [PMCfree article] [PubMed]

14- Xu GY, Lv GC, Chen Y, Hua YC, Zhu SM, Yang YD. Monitoring the level of serum paraoxonase 1 activity in liver transplantation patients. Hepatobiliary Pancreat Dis Int. 2005; 4:178-81. [PubMed]

15- Zhang C, Peng W, Jiang X, Chen B, Zhu J, Zang $\mathrm{Y}$, et al. Transgene expression of human PON1 Q in mice protected the liver against $\mathrm{CCl} 4$ - induced injury. J Gene Med. 2008; 10:94-100. [PubMed]

16- Marsillach J, Camps J, Ferré N, Beltran R, Rull A, Mackness B, et al. Paraoxonase-1 is related to inflammation, fibrosis and PPAR delta in experimental liver disease. BMC Gastroenterol. 2009; 9:3. [PMC free article] [PubMed].

17- Kedage V, Muttigi MS, Shetty MS, Suvarna R, Rao SS, Joshi C, Parakash M, Saudi J Gastroenterol. 2010 Apr; 16(2): 79-83. 
18- Belanger, L., C. Sylvestre, and D. Dufour. Enzymelinked immunoassay for Alpha-fetoprotein by competitive and sandwich procedures. Clinica. Chimica. Acta, 1973, Volume 48, issue 1, 28 Sept 1973, pages 13-15.

19- Ackerson LM, Lepper K,Robbins S, Go AS, Yang J, Associated antioxidant enzyme paraoxonase (PON) 1 and higher concentration of lipid. Biophys Res Commun 1983; 113:666-71.

20- Sanghera DK, Christopher E Aston, Nilmani Saha, M llias kampoh et al. DNA Polymorphisms in Two Paraoxonase Genes (PON1 and PON2) Are Associated with the Risk of Coronary Heart Disease, $A J H G$, Volume 62, Issue 1, January 1998, Pages 36-44

21- El-Serag H.B., Marrero J.A., Rudolph L., et al. Diagnosis and treatment of hepatocellular carcinoma. Gastroenterol, 2008. 134,1752-63.

22- Abdel Wahab AH, El-Halawany MS, Emam AA, Elfiky A, Abd Elmageed ZY. Identification of circulating protein biomarkers in patients with hepatocellular carcinoma concomitantly infected with chronic hepatitis C virus. Biomarkers: 2017 Nov, 22(7): 621-628.
23- Huang, C, Wang, YW, Liu, SD, Ding, GY, Liu, WR, Zhou, J, Kuang, M., Ji, Y, Kondo, T, Fan, J. Quantitative proteomic analysis identified paraoxonase 1 as a novel serum biomarker for the microvascular invasion in hepatocellular carcinoma. J. Proteome Res., 2013. 12(4), 1838-

24- Zhang S, Jiang K, Zhang Q, Guo K, Liu Y. Serum fucosylated paraoxonase 1 as a potential glycobiomarker for clinical diagnosis of early hepatocellular carcinoma using the ELISA Index. Glycoconjugate Journal, 2015, 32(3-4), 119125.

25-Ferré N, Marsillach J, Camps J et al. Paraoxonase1 is associated with oxidative stress, fibrosis and FAS expression in chronic liver diseases. $J$ Hepatol, 2006, 45:51-59

26- Marsillach J, Ferré N, Vila MC et al. Serum paraoxonase-1 in chronic alcoholics: Relationship with liver disease. Clin Biochem, 2007, 40: 645650

27- Sugano M, Tsuchida K, Makino N. High-density lipoproteins protect endothelial cells from tumor necrosis factor-a-induced apoptosis. Biochem Biophys Res Commun, 2000, 272: 872-876.

28- Nofer JR, Kehrel B, Fobker M, et al. HDL and arteriosclerosis: beyond reverse cholesterol transport. Atherosclerosis, 2002, 161:Issue 1, pages $1-16$. 